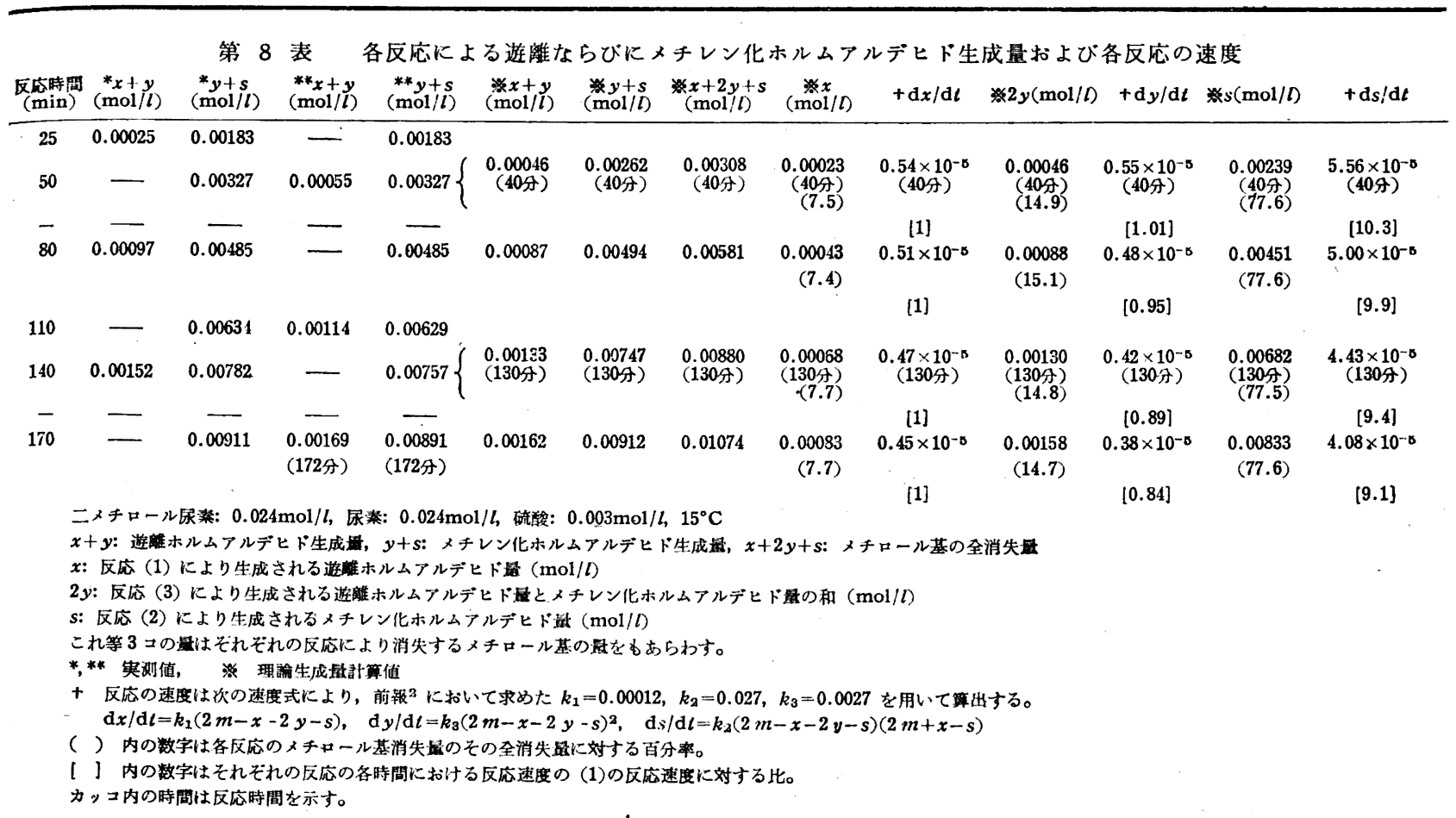

（昭和 29 年 4 月, 日化第 7 年会講演)

\title{
（225） スルホニウム塩基型イオン交換樹脂の諸性質
}

（昭 和 30 年 7 月 28 日 受 理)

中 村 儀 郎*

\section{I. 緒䓂}

スルホニウム基を有するアニオン交換樹脂としては trianisyl sulfonium chloride のような芳香族第 3 級スルホニウム化合物 をアルデヒド類と縮合してらるもの1) と，著者がすでに報告した チオール基を有する不溶性高分子体を原料とする脂肪族性のも の2) とが知られているが，この新しい型の交換樹脂の性質関す る詳細な報告は未だなく，ただ前者汇関する特許抄録中に当交換 樹脂が脱ヶイ酸能を有することが付記してある程度にすぎない。 しかし, 当交換樹脂は強塩基性樹脂（Amb. IRA-410）と弱塩基 性樹脂 (Amb. IR-45) の中間程度の塩基度を有 (2), 将来広く 利用されることが予想されるので，ここにその諸性質について報 告する。

なお実験に使用した試料は東洋レーヨン株式会社の履ポバール (揮発分 23\%，酢酸ソーダ 9.5\%，P.V.A. $70 \%$ ，重合度 1000 〜1100）をそのまま前報汇述べた処方2てで処理して得た OH-R 型 試料（全イオウ $18.43 \%$ ，粒度 50 メッシュ全通， $0.1 \mathrm{~N}$ 塩酸に 対する交换能 $2.45 \mathrm{~m} . \mathrm{eq} / \mathrm{g} \cdot \mathrm{OH}-\mathrm{R}$ ) で, Cl-R 型陚料は $\mathrm{OH}-\mathrm{R}$

†本報を「官能基を有する高分子体の研究（第 16 報）上す る。

* 岩手大学工学部化学教室：盛汕市

1) D.P. $72245,73798,73966$ (1953); Chem. Abst. 48, $12703,8448,12342$ (1954).

2) 中村, 工化 58, 271 (1955).
型試料を $1 \mathrm{~N}$ 塩酸と一夜接触後, 口別して洗浄液中に塩素イオ ンが認められなくなるまで水洗後, アルコール，エーテルで脱水 し，さらに室温で真空乾燥したものである。

\section{II. 交換基の塩基度}

$1 \mathrm{~N}$ 塩化カリ溶液の共存下で $\mathrm{OH}-\mathrm{R}$ 型試料の滴定曲線を常 第 1 困

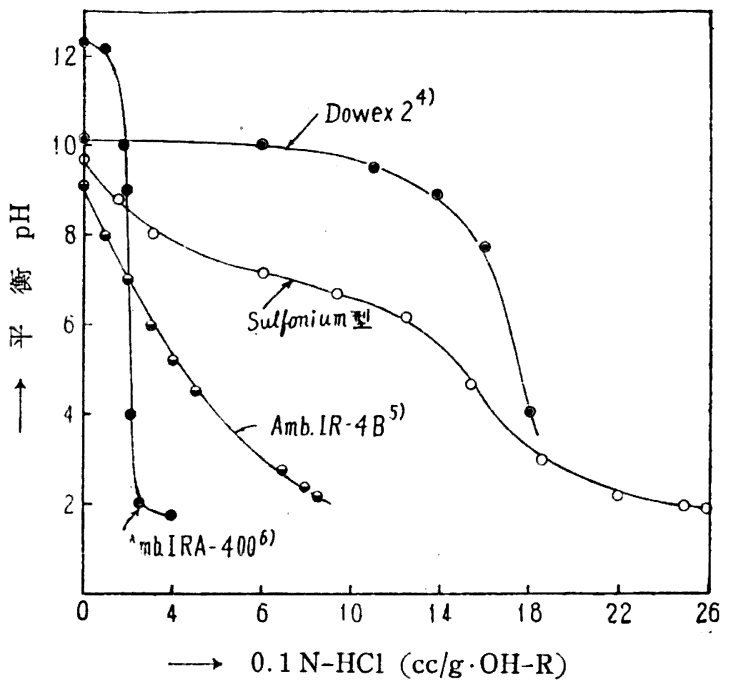

3)“清水，イオン交換樹脂 p. 87, 127 (1953). 
法3)によりガラス電極を用いて画き（第1図)，市販アニオン交 換樹脂のそれと比較した。

一般にアニオン交換樹脂の見掛けの解離恒数 $p K$ は (1) 式 ${ }^{3)}$ により求められるから, 各交換樹脂の交換基の解離度 $\alpha$ を 0.5 とした時の基準解離恒数 $p K_{\mathrm{s}}{ }^{7)}$ は第 1 図より概略次のようにな る。

$$
\mathrm{pH}=p K_{\mathrm{W}}-p K-\log \alpha /(1-\alpha)
$$

Amb. IR-4 B : $p K_{\mathrm{f}} \fallingdotseq 9>$ Sulfonium 型 : $p K_{\mathrm{B}} \div 7.5 \sim 8.5>$

Dowex 2: $p K_{\mathrm{s}}=4.5>$ Amb. IRA-400: $p K_{\mathrm{s}} \fallingdotseq 2$

当交換樹脂の滴定曲線の終点付近の傾斜は期待したほど急でな く，スルホニウム基の塩基度に不均一性があるよ５に思われる が, その塩基度は市販弱塩基性樹脂より幾分強いことが理解され る。

\section{III. 熱 安 定 性}

当交換樹脂は室温で僅かに特臭を発し，また 12 カ月の保存に より $\mathrm{OH}-\mathrm{R}$ 型試料の交换能は $3.87(\mathrm{~m}$. eq $\mathrm{HCl} / \mathrm{g})$ から 2.61 (m. eq $\mathrm{HCl} / \mathrm{g}$ ) に減少することなどからやや不安定なことが想像 されるが，この耐熱性をDowex 2 と比較して第 2, 3 図に示し た。

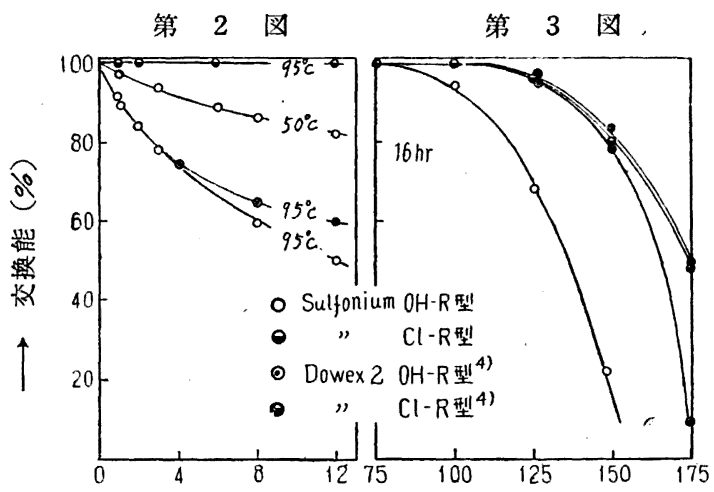

$\longrightarrow$ 熱処理時間 (day) $\longrightarrow$ 熱処理温度 $\left({ }^{\circ} \mathrm{C}\right)$

すなわち, 当交換樹脂の熱安定性は一般にDowex 2 に少るこ とが明らかで， OH-R 型試料の交換能は $100^{\circ} \mathrm{C}$ 以上で急激に隇 少するが， Cl-R 型試料は $95^{\circ} \mathrm{C}$ 程度では十分な安定性を有する ことが理解される。

\section{IV. 再 生 条 件}

$\mathrm{Cl}-\mathrm{R}$ 型試料 $1 \mathrm{~g}$ に対して種々のアルカリを $0.1 \mathrm{~N}$ として添 加し，24 時間後に遊離した塩素イオンをVolhard 法で定量し両 者の関倸からいわゆる再生滴定曲線5)を得た（第 4 図）。

第 4 図から Cl-R 型試料に対する各種アルカリの再生能力は $\mathrm{NaOH}>\mathrm{Na}_{2} \mathrm{CO}_{3}>\mathrm{NH}_{4} \mathrm{OH}>\mathrm{NaHCO}_{3}$ となり，アニオンの種類 ( $\mathrm{V}$ の項参照) 以外に溶液の $\mathrm{pH}$ に影響されることが理解される。

\section{V. アニオン交換平衡}

抢もな 1 価のアニオンのナトリウム塩の $0.1 \mathrm{~N}$ 溶液 $20 \mathrm{cc}$ を $\mathrm{Cl}-\mathrm{R}$ 型陚料約 $0.5 \mathrm{~g}$ と 24 時間接触させたものについて (2)

4) $\mathrm{KCl}$ 添加せず。Wheaton, Bauman, Ind. Eng. Chem. 43, 1088 (1951).

5) Kunin, Myers, J. Am. Chem. Soc. 69, 2874 (1947).

6) Kunin, Anal. Chem. 21, 87 (1949).

7）香川, 笠師, 工化 53, 126 (1950).

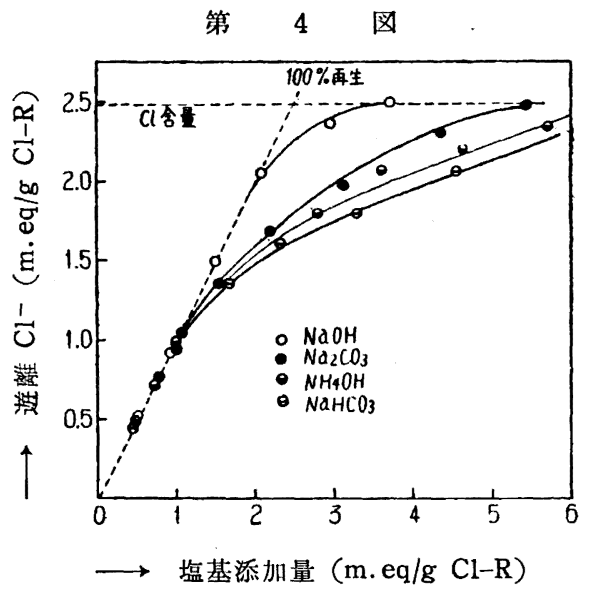

式)にしたがって交換平衡恒数を求めて第 1 表に示し，カッコ内

$$
K_{\mathrm{Cl}}^{\mathrm{A}}=\frac{\mathrm{A}_{\mathrm{R}} \cdot \mathrm{Cl}}{\mathrm{Cl}_{\mathrm{R}} \cdot \mathrm{As}_{\mathrm{s}}}
$$

に塩素イオンの樹脂内モル分率を付記し，さらに当交換樹脂の $\mathrm{Cl}^{-} \sim \mathrm{OH}^{-}$交換平衡を市販アニオン交換樹脂のそれ( $)$比較した (第 5 図)。

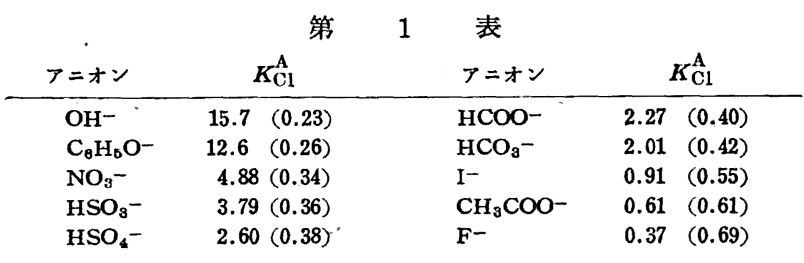

第 5 図

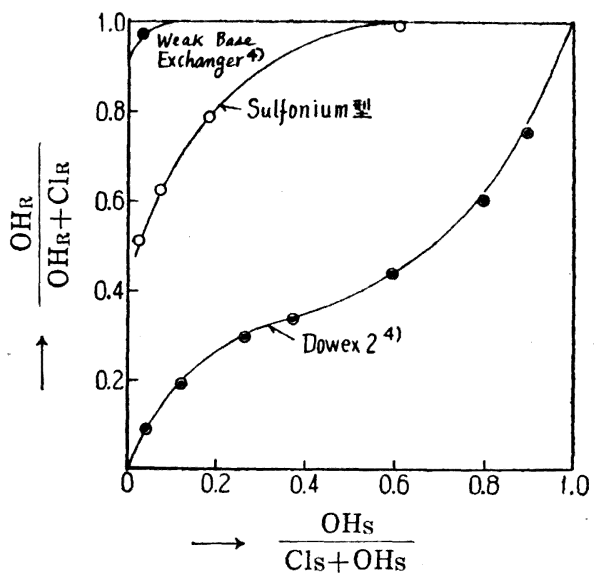

これらの結果からおすなアニオンに対する交換順位が判定でき るが，水酸イオンが比較的置換し難いアニオンであることは弱 塩基性樹脂（Amb. IR-4 B) の場合 ${ }^{5)}$ と同様で，強塩基性樹脂 (Dowex 1，2）の交換順位 ${ }^{4}$ ) と著しく異なる点であり，当交換樹 脂がカセイアルカリによって容易に再生できることが理解され る。

また，上に示した $K_{\mathrm{Cl}}^{\mathrm{A}}$ の值は塩素イオンの樹脂内モル分率に より異なるが，その若干の例として $\mathrm{Cl}^{-} \sim \mathrm{NO}_{3}{ }^{-}, \mathrm{Cl}^{-} \sim \mathrm{SO}_{4}{ }^{2-}$ の交換平衡に対する結果を四示した（第 6,7 図）。

与なわら第 6,7 図は OH-R 型試料に対して塩酸と硝酸また は硫酸の混酸（初期全酸濃度約 $0.25 \mathrm{~N}$, 平衡全酸濃度的 $0.20 \mathrm{~N}$ ) を用いた場合7)であるが， $K_{\mathrm{Cl}}^{\mathrm{A}}$ の值の変動は第 7 図に示したよ らになる。 


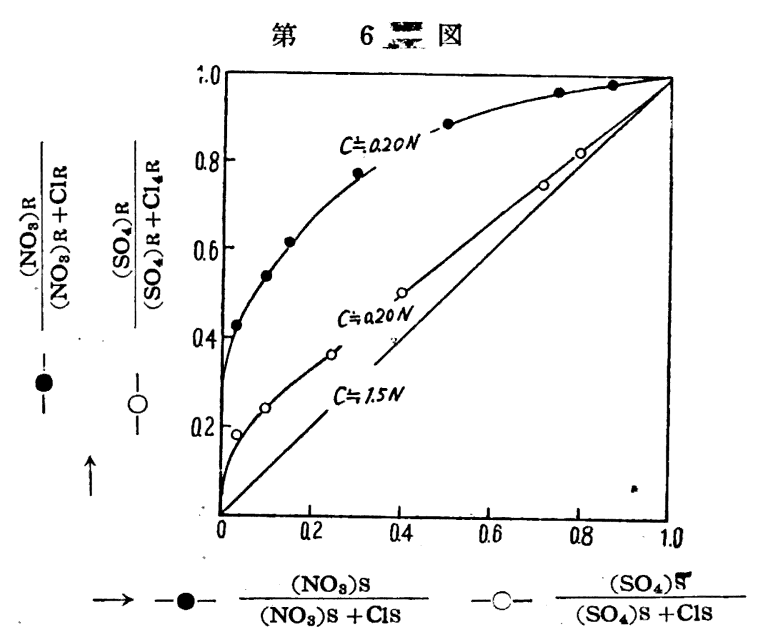

第 7 図

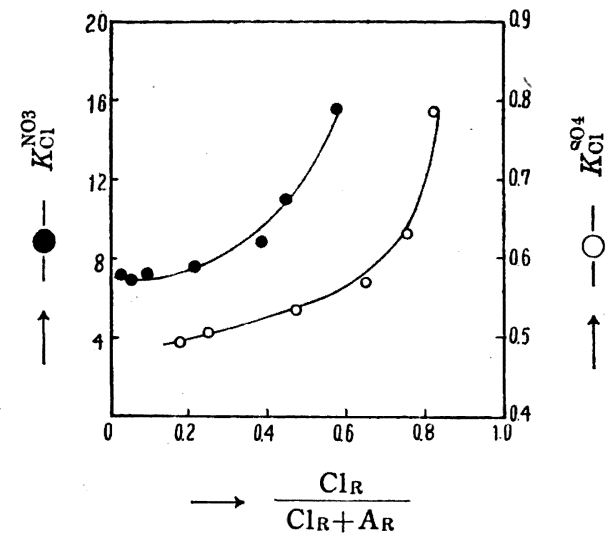

さらに $\mathrm{Cl}^{-} \sim \mathrm{SO}_{4}{ }^{2-}$ 交換において溶液濃度により交換順位が逆 転することが Amb. IR-4 B, Dowex 2 について明らかにされ ており，それぞれ限界濃度として $\left.1.2^{8)} ， 0.18 \mathrm{~N}^{4}\right)$ が得られてい るが，当交換樹脂についても同様な現象が見られ，約 $1.5 \mathrm{~N} \% 1$ 以上で交換順位は $\mathrm{Cl}^{-}>\mathrm{SO}_{4}{ }^{2-}$ と逆転することが認められる。

\section{VI. 脱 酸 現 象}

塩酸, 硫酸, リン酸, 酶酸, 硫化水素およびホウ酸を $\mathrm{OH}-\mathrm{R}$ 型試料に対して 100 倍量用いて 24 時間室温で接触したものにつ いて, 樹脂の結合酸量 (m. eq/g OH-R) を求め, 平衡溶液の $\mathrm{pH}$ あるいは濃度との関係を第 8,9 図に示した。

8) Nachod, Ion Exchange Theory \& Application p. 73 (1949).

$※ 1 X_{\mathrm{R}} /\left(1-X_{\mathrm{R}}\right)^{2}=\left(K_{\mathrm{Cl}}^{\mathrm{A}} \cdot C_{\mathrm{R}} / C_{\mathrm{s}}\right)\left(X_{\mathrm{S}} /\left(1-X_{\mathrm{S}}\right)^{2}\right)$ において $K_{\mathrm{Cl}}^{\mathrm{A}} \cdot C_{\mathrm{R}}=1.5$ とした。たたし $X_{\mathrm{R}}=\left(\mathrm{SO}_{4}\right)_{\mathrm{R}} /\left(\left(\mathrm{SO}_{4}\right)_{\mathrm{R}}+\right.$

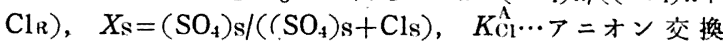
平衡恒数, $C_{\mathrm{R}} \cdots$ 樹脂の総アニオン交換能 $(\mathrm{m} . \mathrm{eq} / \mathrm{g}), C_{\mathrm{s}} \cdots$ 溶液の全アニオン $(\mathrm{N})$.

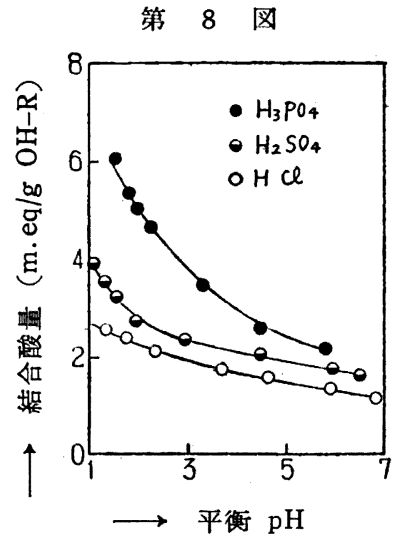

塩酸, 硫酸、リン酸に対する 脱酸曲線は弱塩基性樹脂（ダイ アイオン $\mathrm{A}^{7)}$, Amb. IR-4B $\mathrm{B}^{5)}$ ) についてすでに報告されている が，硫酸、リン酸に対する過剩 吸着性はこれらと同様にうかが われるが，当交換樹脂の塩基度 が幾分強いためか平衡溶液の $\mathrm{pH}$ の上算にともなう吸着能の 減少程度は他の交換樹脂に比較 して少なく, また硫化水素, ホ ウ酸のよ 5 な多価極弱酸に対し ても過剩吸着性を有することを

明らかにすることができた。

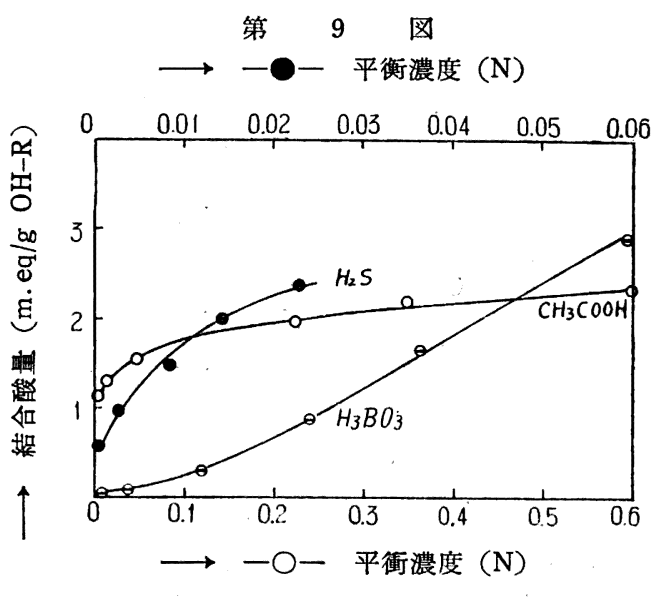

VII. 総 括

ポリビニルアルコールを原料とした脂肪族性スルホニウム塩基 型アニオン交換樹脂の諸性質を検討して次の結果をえた。

1. 交換基の塩基性度は基準解離恒数として約 7.5〜8.5 とな り，市肘弱塩基性樹脂上り幾分強い塩基性を示す。

2. $\mathrm{OH}-\mathrm{R}$ 型試料の耐熱性は Dowex 2 に少るが, $\mathrm{Cl}-\mathrm{R}$ 型試 料は $95^{\circ} \mathrm{C}$ 程度で安定である。

3. Cl-R 型試料の再生はカセイソーダで容易に行われること を再生滴定曲線および $\mathrm{OH}^{-} 〜 \mathrm{Cl}^{-}$交換平衡から明らかにした。

4. $\mathrm{Cl}-\mathrm{R}$ 型試料に対するおるお 1 価アニオンの交換順位を決 定し, $\mathrm{OH}-\mathrm{R}$ 型試料を用いて $\mathrm{Cl}^{-} \sim \mathrm{NO}_{3}{ }^{-}, \mathrm{Cl}^{-} \sim \mathrm{SO}_{4}{ }^{2-}$ 交換に おける交換平衡恒数と塩素イオンの樹脂内モル分率との関係を明 らかにした。

5. $\mathrm{OH}-\mathrm{R}$ 型試料の $1 ， 2 ， 3$ 洒の酸類に対する脱酸曲線を画 き, 当樹脂が多価極弱酸に対しても過剩吸着性を有することを明 らかにした。 